\title{
ENTREPREUNARIAL AND FAMILY BUSINESS FARMS IN THAILAND: WHO TOOK ADVANTAGE OF THE RUBBER BOOM?
}

\section{Bénédicte Chambon ${ }^{1,2 *}$, Pierre-Marie Bosc ${ }^{3}$, Arunee Promkhambut ${ }^{4}$, Kanchana Duangta ${ }^{5}$}

\author{
${ }^{1}$ CIRAD, UPR Systèmes de pérennes, HRPP, Kasetsart University, 10900 Bangkok, Thailand \\ ${ }^{2}$ UPR Systèmes de pérennes, Univ Montpellier, CIRAD, Montpellier, France \\ ${ }^{3}$ FAO, CBL Division, B724 Department Climate Change Biodiversity, Land and Water Via \\ delle Terme di Caracalla, 00153 Roma, Italy \\ ${ }^{4}$ Khon Kaen University, Faculty of Agriculture, Khon Kaen 40002, Thailand \\ ${ }^{5}$ CIRAD, Kasetsart University, 10900 Bangkok, Thailand \\ *Corresponding author e-mail: benedicte.chambon@cirad.fr
}

Citation: Chambon, B., Bosc, P.M., Promkhambut, A., Duangta, K. 2018. Entrepreunarial and Family Business Farms in Thailand: Who took advantage of the rubber boom? J. Asian Rur. Stud. 2(2): 173-195

\begin{abstract}
Following the high rubber prices in the second half of the 2010s, rubber plantations expanded greatly especially in Southeast Asia. Smallholders were important actors of the recent rubber boom. However, large landholdings and foreign investments were also very present in some Southeast Asian rubber producing countries leading some researchers to ask whether we are witnessing resurgence of plantations in tropical Asia. Looking at entrepreneurial rubber farms in Thailand, the first producer of natural rubber in the world, where very little information is available on this type of farms, is one way to contribute to the debate. After identifying large rubber holdings using secondary data completed by some field explorations, we conducted a survey on a limited number (13) of large rubber holdings. Qualitative analysis revealed that the recent development of large plantations in the rubber sector was actually limited in Thailand, and that this (limited) expansion of large rubber plantations mainly involved family business farms. Together with family farms, these family business farms largely contributed to the recent expansion of rubber plantations rather than entrepreneurial farms. In addition, these large landholdings shared several similar technical and organizational patterns with smaller family farms. Finally, Thailand represents a specific pattern of change in farm structure in which family farms have always persisted over enterprise farms. Family business farms are a type of farm structure that now appears to be expanding. In addition to continuing to support small and medium family farms, government policies should consider such changes in farm structure and provide support to improve the technical management of these developing forms of production. In parallel, support should be provided to help maintain the smallholdings thereby limiting land concentration when it is not wanted by the owners.
\end{abstract}

Keywords: Farm structure; Large Landholdings; Rubber; Thailand 


\section{Introduction}

Since the beginning of the rubber industry, there has been a clear distinction between "estates" and "smallholdings". The estates were characterized by their size, substantial operating capital and large hired labor force. Smallholdings owned small areas operated by family labor occasionally assisted by external labor. In many producing countries, the rubber sector first developed through estates. In 1929, countries such as Malaya, Indonesia, Ceylon, India and French Indochina accounted for a large share of rubber estates. At that time, the great majority of estates were owned by European or American interests. Later, smallholders developed rubber plantations and became major stakeholders in natural rubber production in most countries. The pattern of development of the rubber sector in Thailand was different. It was the only country with no estates at all and few smallholdings in 1929 (Bauer, 1948). One possible explanation for this specificity was that, unlike other rubber producing countries, Thailand had never been colonized by western countries. Indeed, some authors consider that estates are a form of farm organization brought to tropical Asia by the West (Hayami, 2002). In addition, some authors considered that one reason for the slow development of rubber plantations in Thailand in the late 19th century was the absence of direct government encouragement of foreign plantation development (Stifel, 1973; Sakarindr, 1979). Large scale land acquisitions by European capital were in fact limited by formal and informal restrictions at the beginning of the 20th century (Larsson, 2007). As a result, rubber plantations expanded through local initiatives. Some plantations could have been established at a relatively large scale, in particular by Chinese planters since they were targeting full family employment. However, most holdings were less than 8 ha. The situation was very different from that in neighboring rubber producing countries. For instance, in Malaya, Europeans were allowed to run estates over 64,000 ha in size while the largest Sino-Thai family estates accounted for only 480-800 ha (Stifel, 1973). Finally, it is clear that throughout the history of rubber development, Thailand "made a conscious institutional decision to support smallholder rubber production" (Fox and Castella, 2013 p.167) which has always dominated the sector.

However, recent changes suggest that the types of holdings involved in rubber production are changing as a consequence of the rubber boom that happened a few years ago in South East Asia, rubber plantations expanded notably in non-traditional producing areas. Entrepreneurs invested in the non-traditional areas in their own and neighboring countries (Fox and Castella, 2013). Field work in Thailand suggested that increasing numbers of investors and big companies planted rubber particularly in the new rubber producing areas, in the North and the Northeast regions (unpublished interviews by the authors in 2012 with different stakeholders of the rubber chain at the national and provincial levels).

In fact, the figures provided by the Land Matrix initiative show that, together with Africa, South East Asia is a core target of foreign investments in rubber production. These foreign investments mostly target Cambodia (45\% of the area concerned by registered deals), Papua New Guinea (30\%), followed by Indonesia (14\%), Lao PDR $(10 \%)$, and Myanmar accounting for only $2 \%$ of these deals. There is no mention of Thailand in these figures. Nevertheless, preliminary field work suggested that large scale plantations are present and have recently expanded. This suggests that until now, only domestic investors were involved in Thailand. 
Consequently, these recent land acquisitions are probably far from the situation of transnational land grabbing that is currently creating international tensions concerning land issues (Petric, 2011). However, these dynamics are poorly documented in Thailand. These new investments would necessarily lead to changes in the land property relations and in the social relations around production (Kenney-Lazar, 2012; Borras and Franco, 2012). These new stakeholders might compete with small farms for land and also for labor. On the other hand, they might also represent new opportunities for small family farms. The smallholders' adaptive capacity may be challenged by these changes with consequences for both the sustainability of the plantations and for the environment.

Looking at large scale rubber plantations in Thailand is one way to contribute to the debate sparked by Byerlee (2014): are we witnessing a resurgence of plantations in tropical Asia? This question has its origins in an historical perspective that highlighted the fact that this move towards industrial plantations was driven by "remarkably similar drivers [than] early in the previous century-high commodity prices, biased policies reflecting a new political economy of converging investor-state interests, and prevailing beliefs about the modernity of large agribusiness operations". To understand what happened in Thailand, a country that has historically focused on family farming, the aim of this study was to empirically document the development dynamics of large landholder farming in Thailand that goes along with a period of high world market prices in the 2000s. The first objective was to identify a possible wave of land concentration leading to entrepreneurial rubber farming based exclusively on hired labor. If this was the case, the second objective was to characterize the dynamics controlling the organization of labor and the technical choices made with respect to these large farms.

\section{Materials and methods}

\subsection{Conceptual framework}

The methodological framework was developed under the international initiative 'World Agricultures Watch' that relies on standard definitions (FAO, 2007) while adding an analytical definition of the types of farms (Belières et al., 2015) based on the type of labor used (Table 1).

Table 1. Classification of the forms of production

\begin{tabular}{llll}
\hline & Entrepreneurial farming & Family farming \\
\hline Criteria & Enterprise & Family business farms & Family farms \\
\hline Labor & Permanent hired labor & $\begin{array}{l}\text { Mixed family labor and } \\
\text { permanent hired labor }\end{array}$ & $\begin{array}{l}\text { Family labor, no } \\
\text { permanent hired workers }\end{array}$ \\
Capital & $\begin{array}{l}\text { Shareholders / Private } \\
\text { sector }\end{array}$ & Family & Family \\
\hline
\end{tabular}

Source: Belières et al., 2015

The Sustainable Rural Livelihoods approach was also adapted, especially to characterize the various assets mobilized for production purposes. In this study, the types of assets are not detailed but instead the varied nature of activities is identified. 
The definition of the types of farming proposed makes sense and is "robust" across different institutional and political contexts as well as across the diverse farming systems within a given country (which is the case of this paper). This definition is analytical as it makes it possible to use statistics or data (when available) regarding the type of labor used, and consequently to count the different types of farms and assess their contributions.

Enterprise farms were the first focus for this study. They correspond to forms of production characterized by the exclusive use of hired labor in a farm where capital (assets) belongs to private or public stakeholders, excluding organic linkages between capital / assets property and the labor employed at any level of the productive structure. They are characterized by entrepreneurial logics, meaning a search for the highest return (if possible) on investment. Family farming is a broad category based on family logics with strong links between the family and the farm that was split according to the presence / absence of permanent hired labor (Bélières et al., 2015), mainly hired to harvest latex with a specific contractual arrangement in the present case.

This framework was mainly used for entrepreneurial farming vs family business farms aspect. The first step was to identify the nature of the unit of observation: was it a firm or a family run business? In most cases, the diversity of activities implemented by the families or the companies had to be analyzed. After labor and control of the working capital, the second criterion was whether the farm (and other activities) were under family ownership and management or not.

The legal status of the farm is of no use to characterize the type of farm since a family business farm can be run under the same legal registration as an enterprise farm.

Last, the framework goes beyond sector approaches and considers farming as part of a set of activities within which agriculture may not be the main source of income.

\subsection{Empirical data}

Rubber growing areas in Thailand can roughly be divided into two zones. The South and the Center-Eastern region are historical rubber growing areas, where rubber has been grown since the beginning of the 20th century. The Northeast and North are the new rubber-growing areas where rubber plantations started in the 1990s and the 2000s, respectively, and have expanded considerably in the last decade as a result of the significant increase in world rubber price up to 2011. Many smallholders invested in rubber plantations during that period (Chambon et al., 2016). But a previous study conducted by the authors in 2012 also underlined the fact that increasing numbers of investors and large companies have been planting rubber in the last 15 years, particularly in the new rubber producing areas. Therefore, the present study targeted enterprise farms that invested in the North and Northeast of Thailand. In addition to the likely expansion of enterprise farms, one particularity of these regions is that rubber smallholders and enterprise farms expanded more or less at the same time.

The first step of the study was to identify the enterprise farms. No specific list of these farms existed but in early 2015, the Rubber Authority of Thailand (RAOT) was able to establish a list of large farms in Thailand ( 40 ha or more according to the RAOT classification). These could be registered as individuals or under companies' name. The RAOT identified 27 large rubber plantations in the North and 25 in the Northeast. In the North, these plantations were registered under seven companies (some of which had 
several rubber plantations) and six names of individuals. In the Northeast, four companies and 13 individuals were registered. However, the registration name did not systematically make it possible to differentiate the enterprise farms from the family business farms. Therefore, the first step in data analysis was to distinguish enterprise farms from family business farms. As the list provided by the RAOT was probably not exhaustive, it was completed by information collected on Internet and from key persons (such as researchers, companies).

The study areas were selected based on available information on large farms (presence of registered companies) and taking into account field constraints (travelling distances). They included two provinces in the North: Chiang Rai and Phayao and two provinces in the Northeast: Bueng Kan and Udon Thani. The farms identified in the preliminary work were contacted and appointments made. Once in the field, the sample was completed according to information provided by the people met. A total of 13 large farms were surveyed: eight in the North and five in the Northeast.

Data were collected in September-October 2015. A semi-structured interview guide was used to collect information concerning: (i) The farm characteristics, its trajectory, interest in rubber, situation of the rubber sector within the portfolio of activities, plans to expand rubber in the medium and long term; (ii) land acquisition modalities, land status and possible limits to extension; (iii) the origin of labor, labor organization and labor contracts; (iv) technical model: practices and relationships with RAOT and other public institutions, and (v) relationships/interactions with the smallholders.

\section{Results}

\subsection{Characteristics of the large rubber landholdings}

Despite intensive investigation, finally the number of large farms was quite limited. As mentioned above, the first step of the analysis was to distinguish family business farms from the enterprise farms. Referring to the definition given by Bélières et al. (2015), this was possible using two key variables: origin/ownership of the assets and labor use (Table 2). Among the 13 interviews conducted, only four enterprise farms emerged that belong to three companies (one company in the sample had two holdings, one in the Northeast, the other in the North). The nine other holdings were family business farms (FBF). The ownership was under family control in all cases except one in which the farm was run by a company that included non-family shareholders but who had been recruited among close friends.

Table 2. Distribution of the sample in two types of holdings based on two key variables

\begin{tabular}{lll}
\hline & Enterprise farms & Family business farms \\
\hline Assets ownership & Shareholders & Family/close friends \\
Labor use & Hired labor & Hired labor \\
Number of holdings & 4 & 9 \\
\hline
\end{tabular}

Plantation activities can be officially registered, but this is not compulsory. The companies can register at the Department of Business Development at the provincial level.

One of the enterprise farms was registered as a Limited Company. This kind of company "is formed with a capital divided into equal shares, the liability of the 
shareholders being limited to the amount unpaid on the shares respectively held by them." There is a separation between the owners and the management. The two other enterprises were registered as Public Limited Company. This kind of company "established with the purpose to offer shares for sale to the public and the liability of the shareholders is limited to not exceeding the amount payable on the shares and said company has specified such objective in its Memorandum of Association." Both Public Limited Companies started as a Limited Company (as a family business in both cases) before the shares were opened to public subscription a few years later probably to increase their financial capacity. However, because it was not possible to meet the top management (team) of the different enterprises during this study, it is difficult to justify the choice of the enterprise for one status or the other, and in particular why the Limited Company has not (yet) opened its shares to public to become a Public Limited Company.

Half of the FBF registered as a Limited Company and the other half under individual names. The holdings with the largest rubber area (more than 400 ha) were all registered as a company and the holdings with the smallest areas (less than 200 ha) were registered under individual names. This suggests that there may be economic advantages for large landholdings to register as a company (such as lower level of taxation). In addition, the five FBF that registered as companies all had diversified activities, or were part of a bigger group with diversified activities, whereas those that were registered under individual names focused on farming. Registration under individual names and not a company was mentioned by the interviewees as a way to limit taxes on land and income. Registration under the names of several family members could also facilitate inheritance. For large scale activities, registering as a company was said by the interviewees to be better but this probably has a cost for registration and in terms of management.

The sample included one small FBF with less than 40 ha of planted rubber at the time of the survey. Actually, this farm was supposed to own more than 40 ha; but the owner had recently felled part of the plantation (11 ha corresponding to one fourth of total rubber plantation) reducing the area of rubber to 32 ha. For the rest of the sample, the total area planted with rubber ranged from 112 to 1,440 ha. Although enterprise farms were among the largest landholdings, some FBF owned larger rubber plantations than enterprises (Figure 1).

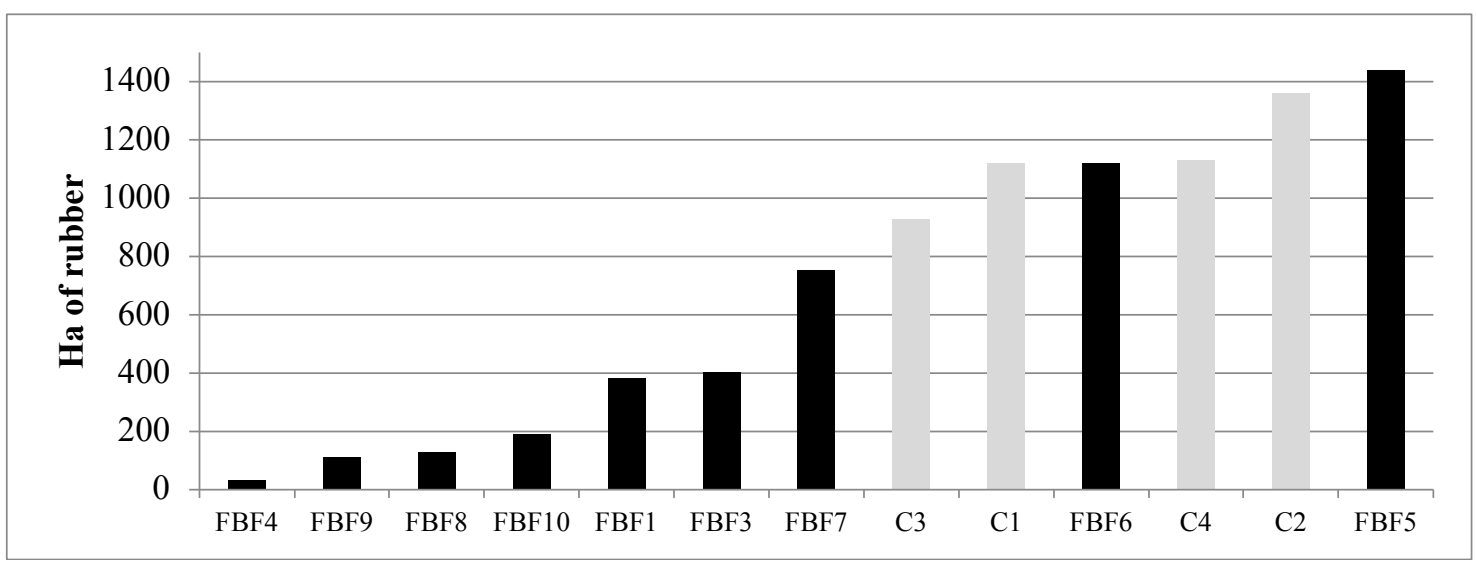


Figure 1. Size of the rubber plantation belonging to the different enterprises and family business farms Grey bars are enterprises (C) and black bars are family business farms (FBF)

Locally, enterprise farms could cover large areas, but their expansion was quite limited compared to that of the family farms. The extremely detailed preliminary prospection suggested that the number of enterprises involved in natural rubber remained limited in Thailand. It was confirmed by field interviews.

\subsection{Rubber included in a diversified portfolio of activities}

\subsubsection{The rationale for investing in rubber}

No common pattern emerged from the interviews concerning the decisions to invest in natural rubber. These reasons were specific to each owner.

For the FBF, it could be:

- investors had acquired experience in rubber in the South (historical rubber producing area) and invested in new rubber producing areas because land was available and less expensive than in the South,

- to start an income generating activity, because of high prices, or both,

- to exploit land previously purchased to reduce taxes by taking advantage of the high prices in 2011, following the advice of a friend who was a manager of an enterprise farm,

- local politician willing to develop agriculture for himself and for his family and to demonstrate to other people what could be achieved.

For the enterprise farms, it could be:

- to invest in natural rubber to have full quality control since their core business was rubber processing, while rubber plantations represented a small share of their business activities. The aim was to establish their own quality standard,

- to invest in natural rubber for financial reasons as a long term investment with concerns for environmental quality: planting trees is good for the Earth and the sale of rubber wood represent additional value when replanting,

- to invest in land (that was considered as a good investment since the price of land price continually increases) where it was still cheap; after they checked the suitability of the crop in the area, rubber was selected as a long term investment.

It should however be noted that it was difficult to grasp the real reasons these enterprises invested in natural rubber by interviewing one respondent, who were members of staff and mostly not in the top management team. Surprisingly, the price of rubber did not emerge as the main reason; only two out of 13 farmers interviewed spontaneously mentioned that it was clearly part of the decision to plant.

\subsubsection{Share of rubber in the portfolio of activities}

The 13 farmers interviewed represented a variety of situations regarding the role and place of the rubber plantation.

Many of the holdings included in the sample had long experience in the rubber industry. Four out of the nine FBF interviewed clearly came from families who owned a rubber plantation in the South and one farm had already had rubber plantations in the North since 1996. Two of the three enterprises had been involved in rubber processing for many years and decided to start investing in direct production only relatively recently (in 2000 and 2011, respectively). The third one entered the natural rubber 
sector in 2007 by planting plantations with no previous experience in rubber, but this enterprise was already active in several agrifood businesses.

For five holdings out of the 13 interviewed the rubber plantations represented their only current farming activity. For the other eight, rubber represented 59 to $92 \%$ of their total landholding. This shows that rubber was important in terms of cultivated area except for three holdings (one enterprise and two FBF) for whom land use was more diversified with about $40 \%$ used for other crops (fruit, oil palm, eucalyptus).

Taking two criteria in consideration - the economic weight of rubber in the activity portfolio (including farming and non-farming activities) and the family experience in rubber, four groups could be differentiated by crossing. Whatever the rubber history of the family, rubber appeared to be a diversification activity. For the majority, investment in rubber plantation had been supported by a wide range of diversified activities in multiple sectors (such as running a garage, a plastic company, wood processing factory, manufacturing clothes, construction, gas stations, exporting agricultural products, agrochemicals, mobile phones). In a limited number of cases, the initial activity that allowed rubber investment had ended, but for the majority, the diversity of activities continued. Among the 13 farmers interviewed, rubber was the main business in only two cases (both being new FBF in the rubber sector). For all the others, whether they had previous rubber experience or not, rubber was part of a diversified portfolio of activities (Table 3).

Table 3. Diversification versus specialization for rubber plantations according to the owner's previous experience in rubber

\begin{tabular}{|c|c|c|c|c|}
\hline & \multicolumn{2}{|c|}{$\begin{array}{l}\text { Rubber plantation among other } \\
\text { activities }\end{array}$} & \multicolumn{2}{|c|}{$\begin{array}{l}\text { Rubber plantations main } \\
\text { activity }\end{array}$} \\
\hline & FBF* & Enterprises & FBF* & Enterprises \\
\hline $\begin{array}{l}\text { Previous experience in } \\
\text { rubber }\end{array}$ & 4 & 2 & - & - \\
\hline New in the rubber sector & 3 & 1 & 2 & - \\
\hline
\end{tabular}

\subsection{Land issues}

\subsubsection{Land access through purchase}

The majority of the holdings ran large rubber plots, but rarely at only one location; most ran two to six plots.

In all cases, the land had been purchased. There was no land grabbing like that witnessed in neighboring countries. Land was purchased either as large plots (five cases) or as a large quantity of small plots purchased from smallholders (five cases). Two holdings were a combination of large and small plots while another one had already purchased the land a long time ago. For land acquisition, all the enterprises used the services of middlemen, whereas for most FBF, the transaction was direct with limited use of middlemen. 
Only three holdings (all FBF) purchased the land now planted with rubber all at once. In the other cases, land acquisition was progressive. Land acquisition started in 1990 and continued until 2013; the rubber plantations were established later, mainly starting in the 2000s and continued until 2015, but the largest areas were planted between 2005 and 2014 (Figure 2). This corresponded to the period of the rubber boom in Thailand and more generally in South East Asia.

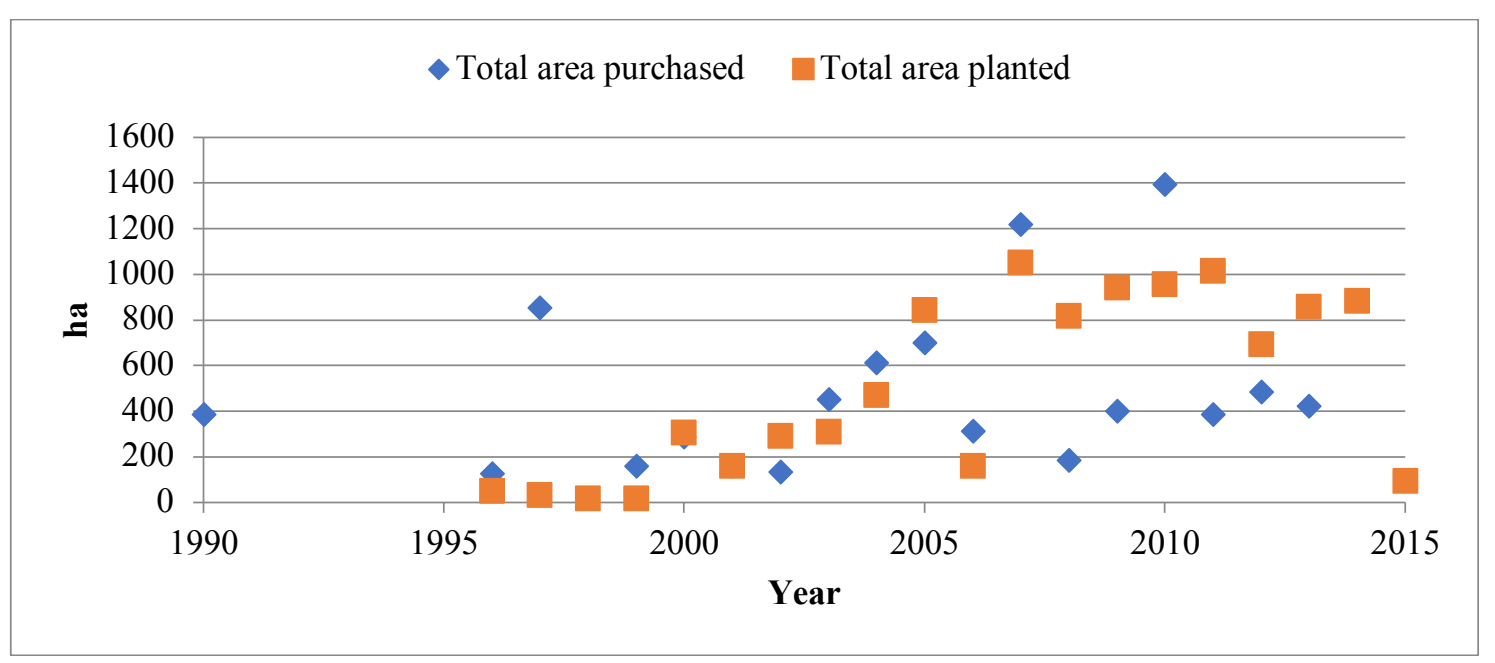

Figure 2. Total area of land purchased and planted with rubber per year

\subsubsection{Land titles and land prices}

All the respondents except one purchased land with at least some official documents. Most bought land with Nor Sor 3 or with Chanote (also called Nor Sor 4). Nor Sor 3 is an official certificate of use. It is usually given to land awaiting a full title deed. Land can be sold, transferred or mortgaged. Nor Sor 3 does not represent a full ownership title but can be transformed into an official land title after filing a request with the Land Department. Chanote is the only title that enables full and certified private ownership of the land. The land is surveyed and its area and boundaries are determined. Chanote is the highest (most secure) land title used in Thailand guaranteeing full rights over the land to use it to the exclusion of others. This probably explains the tendency for respondents to process Nor Sor 3 into Chanote as rapidly as possible.

Three respondents (all FBF) bought land with SPK (Sor Por Kor) only; SPK is an agricultural deed usually found in rural areas. It refers to government owned land that has been transferred to needy families for agricultural purposes, and who are allowed to build a house on a portion of the land. SPK does not establish land ownership and it cannot be converted into full ownership title. The land can be used and transferred by inheritance only; it cannot be sold or used as collateral for a loan. Only one respondent (also FBF) had 30\% of his landholding without any documents until now.

Finally, the trend was to have secure landownership on the land used for rubber plantations but this was not completely systematic.

There was a huge variability of the price of land (constant prices). In the 1990s and very beginning of the 2000s, land was purchased for less than 100,000 THB/ha. After 2004 , the price of land was much higher, above $100,000 \mathrm{THB} /$ ha and up to 300,000 
THB/ha except for the land with only SPK, that remained cheap (Figure 3). In 2015, according to the respondents the minimum price of land was $312,500 \mathrm{THB} /$ ha and up to 2.5 million THB in some locations (current THB) (to the best of their knowledge, because nobody had purchased land that year). The increase in land price combined with the decrease in the price of rubber has probably slowed down the expansion of rubber by new investors.

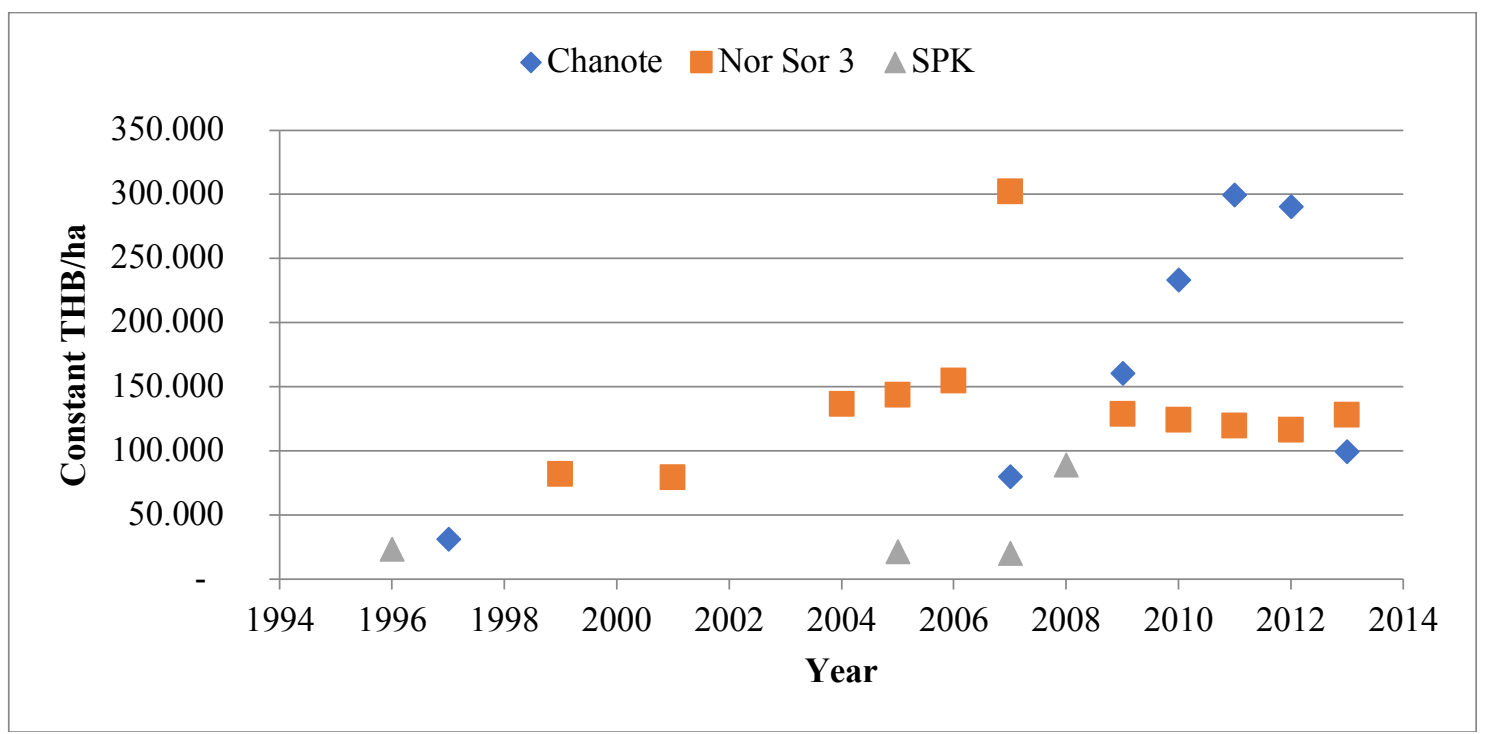

Figure 3. Land price in constant price for different land titles as a function of the year of purchase

\subsubsection{Rubber replaced crops, not forest}

Out of the 13 respondents, nine were able to indicate the previous use of the land where the plantation was established. It is worth noting that no deforestation occurred to plant rubber. In two cases, all the rubber trees were planted on land that was not cultivated because it was located too far from the village (FBF) or part of the plantation was established on unused land (enterprise). But in most cases, rubber was planted on land previously used to cultivate either short term or perennial crops. In the Northeast, rubber plantations replaced maize, cassava, sugar cane and eucalyptus. In the North, the previous crops were more varied with different short cycle crops such as paddy, maize, cassava, pineapple, water melon along with fruit trees such as orange, litchi and longan. To fully grasp the agrarian changes in areas where large rubber plantations have expanded, further investigation should focus on why this land was sold and what their owners became.

\subsubsection{Future developments}

Two out of three enterprises mentioned that they wish to continue investing in rubber plantations but in neighboring countries (Myanmar, Laos, and Cambodia) motivated by easier access to land and the lower cost of labor compared to Thai conditions. 
Even with the low rubber price at the time of the survey, some holdings tended to continue rubber farming but did not expand (the board stopped expansion in Thailand due to the high price of land). Others were even willing to continue extension considering that it is a good strategy to plant when the rubber price is low (less investment required to establish the plantation notably due to lower price of planting material and expected increase of rubber price in the medium term). However, one enterprise considered shifting from rubber to oil palm whose price was good, provided a regular income and was easier to manage than rubber.

Most FBF had no plans to extend their rubber plantations; two of them mentioned the low rubber price as a reason for stopping investments in rubber plantations. Two considered that their rubber plantations were already large enough. Some intended to continue to invest but in other crops than rubber (such as durian to export to China), just to invest in land to reduce taxes or if good land is available, or to invest in other nonagricultural businesses that appeared to be more profitable than rubber plantation. One had already felled part of the rubber plantation (just before opening) and shifted to other quick income generating agricultural activities. Only one FBF intended to continue investing in rubber despite low prices because he expected an increase in the price of rubber in the future.

The general trend was to maintain rubber activity, but to slow down or even stop expanding.

\subsection{Labor issues: organizational patterns and allocation of tasks}

\subsubsection{Hierarchical labor organization}

For the enterprise farms, all employees including high level management were hired on the labor market.

Family members had a leading role in the management of FBF, but in variable contexts. The owners and their close family (often descendants) played a more or less direct role in the management of the plantation. In four out of nine FBF, the manager was a member of the family and in another case, the manager was a classmate of one of the owners, but not a shareholder. In the remaining four cases, the manager was hired on the labor market. But there was a tendency for these management positions to be filled by people who were personal or professional acquaintances of the owners. Labor organization was found to be hierarchical and rather uniform across cases (Figure 4).

The managing director (MD) was not always present: one enterprise and three FBF mentioned the presence of a Managing director (one son of the owner in two cases of family business farms and one brother of the owner in another case). In another FBF, the owner himself was acting as a managing director. The manager and managing director are two different positions: the MD must also be a director of the company. The MD is entrusted with substantial powers in the company. The manager may or may not be the director of the company but is responsible for the management of the whole or almost the whole company. The MD is the top level of organization in the company, responsible for making decisions about everything, and particularly, the most important orientations of the company. In the case of enterprises, the MD has to report to the board and in the case of FBF, the reporting takes place within a "family type of board" the composition of which will vary depending of the shape of the family network of asset ownership. 


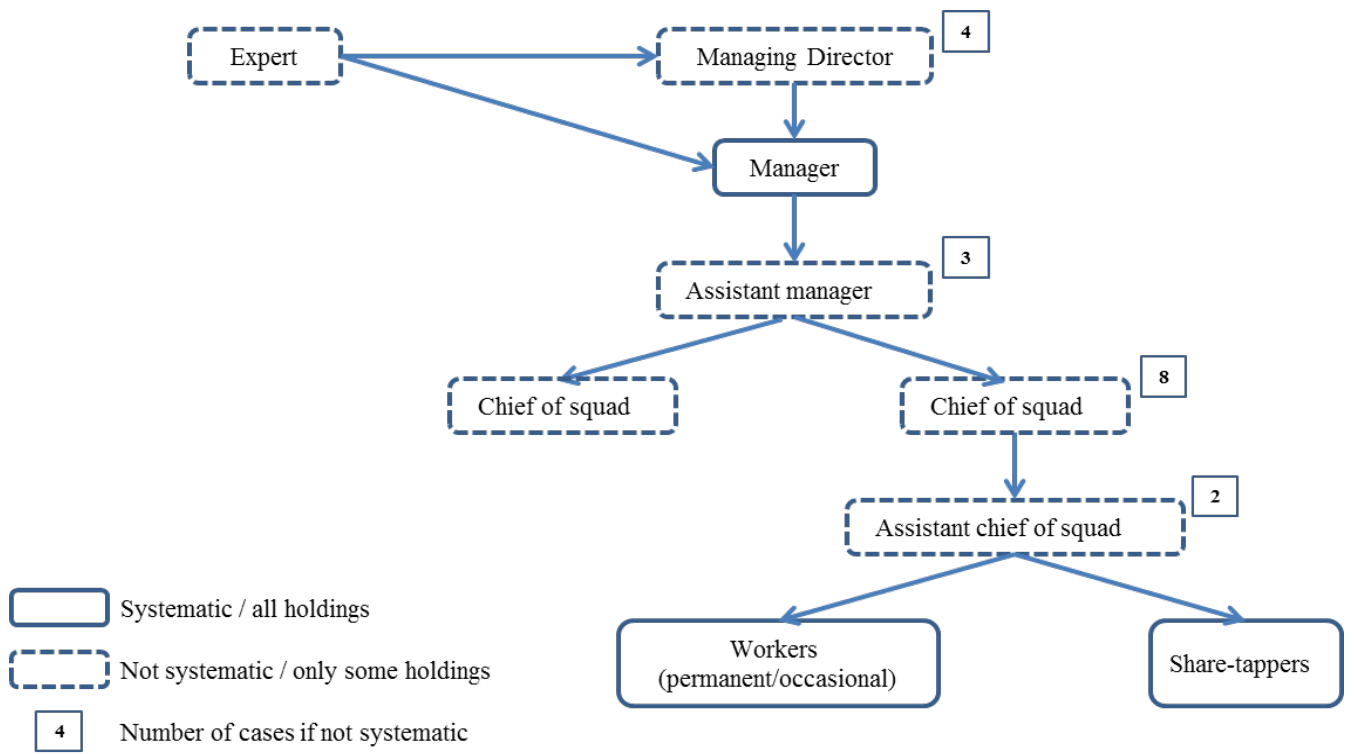

Figure 4. Labor organization

All the holdings had a (plantation) manager who may or may not be supported by an assistant manager ( 3 cases, all FBF). The manager was in charge of the day to day technical decisions, access to information and labor organization. The MD's tasks also mostly included overall supervision and control of the maintenance of the plantation, production operations, labor organization, and sales of the products. The autonomy of the manager ranged from full autonomy (playing the role of MD) to a very limited capacity for decision making with tight supervision by the owner.

Directly under the manager (or assistant manager), the chiefs of squad managed small groups of workers (permanent workers, share-tappers and occasional workers). They were responsible for recruiting, organizing and allocating labor; they also checked the quality of work (notably tapping) and reported to the manager. In a few cases, they could also take technical decisions. Each chief of squad supervised 80 to 160 ha of rubber plantations (up to 800 ha in one enterprise). In the majority of cases, chiefs of squad were recruited locally. Only three FBF had no chiefs of squads, which did not seem to be linked to the size of the holding. In two cases (one FBF and one enterprise), the chiefs of squad had an assistant.

All the enterprises and FBF employed workers (occasional labor, permanent labor or both) for the maintenance of the plantations, both immature and mature plantations or to collect latex. All the workers were recruited locally. They were all local people except one case, a FBF that employed migrants from Burma who were already present in the area. On all the holdings with mature rubber plantations, latex harvesting was done by hired tappers. The majority of the tappers were locals, some had gained experience working in the South, with limited number of southern Thai workers or Myanmar migrants recruited locally in two FBF.

In all three enterprises, experts provided technical support and were not assigned to a specific plantation, but intervened on several sites depending on the needs identified by the managers or managing directors. 


\subsubsection{Payment systems and level of remuneration ${ }^{1}$}

Payment systems differed with the level of responsibilities (Table 4). Most managers received a monthly salary. Only two FBFs paid their manager a percentage of the production or income. There was a huge variability of the level of remuneration among the managers. The two highest salaries (2,706 and 3,823 USD/month) corresponded to the managers of family business farms who received a percentage of the actual production ( $5 \%$ of all production and $50 \%$ of the plantation income). For the others, we identified two groups of salaries: (i) between 294 and 882 USD/month (four cases), (ii) between 1,176 and 1,765 USD/month (four cases). There was no clear evidence of a relation between the level of salary and the type of holding (enterprise versus family business farm). In some FBFs, the manager got twice more than he would get in one enterprise. Two cases appeared to be specific concerning the manager's remuneration: one followed a family farm rationale (what he received after all charges were paid, was the overall farm income including the "management" function) while the other defined a level of income for his work as the manager of the farm. Most managers also received some side benefits such as free housing (for all), a means of transport (for seven) and a means communication (for six). In addition, two managers reported that they received free water and electricity. A bonus was part of the remuneration in all three enterprises but bonuses were rare in FBFs (three out of nine).

All the chiefs of squad received a monthly income. Their wage was homogeneous; differences came from the possible allocation of a bonus.

Two holdings had no mature plantations at the time of the survey. In the other cases, the share-tapping system was quite general and there were only two cases (FBF) that paid by task: 15 USD/1,000 trees tapped in one case, or 9-15 US $\$$ for 1,200 to 2,000 trees tapped in the other case. The first reason for using the share tapping system was that this is the standard in Thailand ( 5 responses) and because it is impossible to find labor if another system is proposed (2). It also appeared to be the best solution as a winwin situation between owner and share-tapper (3), it was easy to implement and manage (2) and it ensured the quality and regularity of tapping as it was an incentive for good work (2). One of the FBF respondents did not use share-tapping arrangement as he considered that with the low rubber price at the time of the interview, the income it provided would not be acceptable for the share tapper (and consequently he would not find a laborer). The other preferred to pay for the labor of tapping per tree considering that production is high (good clone) and so the income for the tapper is good (the laborer is satisfied). In addition, tapping is only a part time job for the laborer, who taps at night and takes care of other farming activities during the day.

In the case of share-tapping, the contract was based on the following distribution of production: $60 \%$ for the owner and $40 \%$ for the share-tapper (eight out of nine holdings) or $50 \%$ for the owner and 50\% for the share-tapper (one holding). This contract applied to the individual allocation of a defined area with an agreed number of trees for tapping. Usually the contract included production cost sharing - using the same ratio - and labor to do it. But, depending on the local situation, the owner may decide to pay for the inputs (fertilizer and chemicals, if used). The share-tappers also received some "sidebenefits" since the owner usually provided them with housing and also paid for their

\footnotetext{
${ }^{1}$ Exchange rate used: $1 \mathrm{USD}=34 \mathrm{THB}$ based on https://www.bot.or.th/
} 
water and electricity. When rubber prices plummeted, some holdings modified the contract ratio to maintain the level of income for the share-tapper (four cases) in order to be able to maintain tapping. In the case of one enterprise, the ratio remained unchanged but stimulation was used to increase production and compensate for the potential loss of income by the tapper. Among those who used the share-tapping system, only two (one FBF and one enterprise) did not change the ratio. One other (FBF), who was only in his first year of production, had not yet been faced with the problem. Paying a bonus to the share-tapper was highly variable. When it existed, it was based on the appreciation of the quality of tapping (depth of the cut, consumption of the bark). The amount paid was variable and ranged from 176 to 529 US\$ a month, i.e. huge variability among those doing it.

Depending on the holdings and on the kind of activity, the workers (i.e. the labor required for tasks other than latex harvesting) could be paid by task (per tree or per area) or with a daily wage. There were marked differences in the level of remuneration depending on the holding and on the topography of the plot (for instance, higher wages for the plots located on slopes).

Table 4. Payment systems and incomes as a function of the level of responsibility

\begin{tabular}{|c|c|c|c|c|}
\hline $\begin{array}{l}\text { Hierarchical } \\
\text { level }\end{array}$ & $\begin{array}{l}\text { Kind of } \\
\text { remuneration }\end{array}$ & Level of remuneration & Bonus & Side benefits \\
\hline Manager & $\begin{array}{l}\text { Mainly monthly } \\
\text { salary or } \\
\text { percentage of } \\
\text { production }(5 \%) \\
\text { or income }(50 \%)\end{array}$ & $\begin{array}{l}294 \text { to } 3,823 \\
\text { USD/month }\end{array}$ & $\begin{array}{l}\text { Not } \\
\text { systematic }\end{array}$ & $\begin{array}{l}\text { Not systematic; } \\
\text { can have } \\
\text { housing, } \\
\text { transportation, } \\
\text { communication }\end{array}$ \\
\hline $\begin{array}{l}\text { Chief of } \\
\text { squad }\end{array}$ & Monthly salary & $\begin{array}{l}294 \text { to } 441 \\
\text { USD/month* }\end{array}$ & $\begin{array}{l}\text { Not } \\
\text { systematic }\end{array}$ & $\begin{array}{l}\text { Not systematic; } \\
\text { same as } \\
\text { manager if any }\end{array}$ \\
\hline Share tapper & $\begin{array}{l}\text { Mainly share- } \\
\text { tapping: } \\
60: 40(8 / 10) \\
\text { 50:50 }(2 / 10) \\
\text { Or task wage }\end{array}$ & $\begin{array}{l}7 \text { to } 21 \\
\text { USD/day/person }\end{array}$ & $\begin{array}{l}\text { Not } \\
\text { systematic; } \\
\text { could be } \\
\text { based on } \\
\text { quality of } \\
\text { tapping }\end{array}$ & $\begin{array}{l}\text { Housing, water } \\
\text { and electricity } \\
\text { when the laborer } \\
\text { was not local }\end{array}$ \\
\hline Worker & $\begin{array}{l}\text { Per task or daily } \\
\text { wage }\end{array}$ & $\begin{array}{l}0.03 \text { to } 0.1 \mathrm{USD} / \text { tree } \\
\text { (fertilization) } \\
4 \text { to } 24 \mathrm{US} \$ / \mathrm{rai}^{* *} \\
\text { (fertilisation, } \\
\text { weeding) } \\
4 \text { to } 12 \mathrm{US} \$ \text { /day }\end{array}$ & None & None \\
\hline
\end{tabular}

* 882 to $1,176 \mathrm{USD} /$ month for the chief of squad controlling 800 ha in an enterprise

$* * 1$ rai $=1600 \mathrm{sqm}$

\subsubsection{Side activities of employees}

"Side activities" cover the activities that the laborer could have outside the contractual arrangement with the owner. The activities included self-farming activities, complementary wage activities on the owner's plantation (cleaning and maintenance of 
the plots for the tappers), fishing in ponds, and wage activities during leaf fall season (in construction). Only the chiefs of squad and share-tappers were included in this category (excluding management staff and occasional laborers). In only one case (FBF) the chiefs of squad had their own agricultural activities on smallholdings (1.6 to $3.2 \mathrm{ha}$ ). In seven cases (both enterprises and FBF), the share-tappers had their own agricultural activities (a paddy field or even a plantation) but on very small areas. Not all employees were in a position to undertake farming activities either because they were local landless or foreigners.

Having access to other activities is important for share-tappers since the latex harvesting period usually lasts 7 to 9 months.

\subsubsection{Focus on latex harvesting: tapping task and supervision}

There were marked differences in the tapping tasks, ie. the number of trees tapped by one person in one day. Tapping task ranged from 600 to 2,000 trees with a concentration around 1,000 trees per tapper per day, which can be considered as a high tapping task. This corresponded to 1.3 to 4.2 ha per tapper, the majority being between 1.6 and 3.2 ha per tapper. The total size of the mature rubber area did not appear to influence the tapping task (Figure 5), nor by the type of holding (enterprise versus FBF), nor by the type of product collected (mainly coagulum; only four holdings collected latex). The trend seems to suggest that the tapping task decreased with an increase in the total rubber harvesting area (Figure 5); but the sample was too small to show clear tendencies.

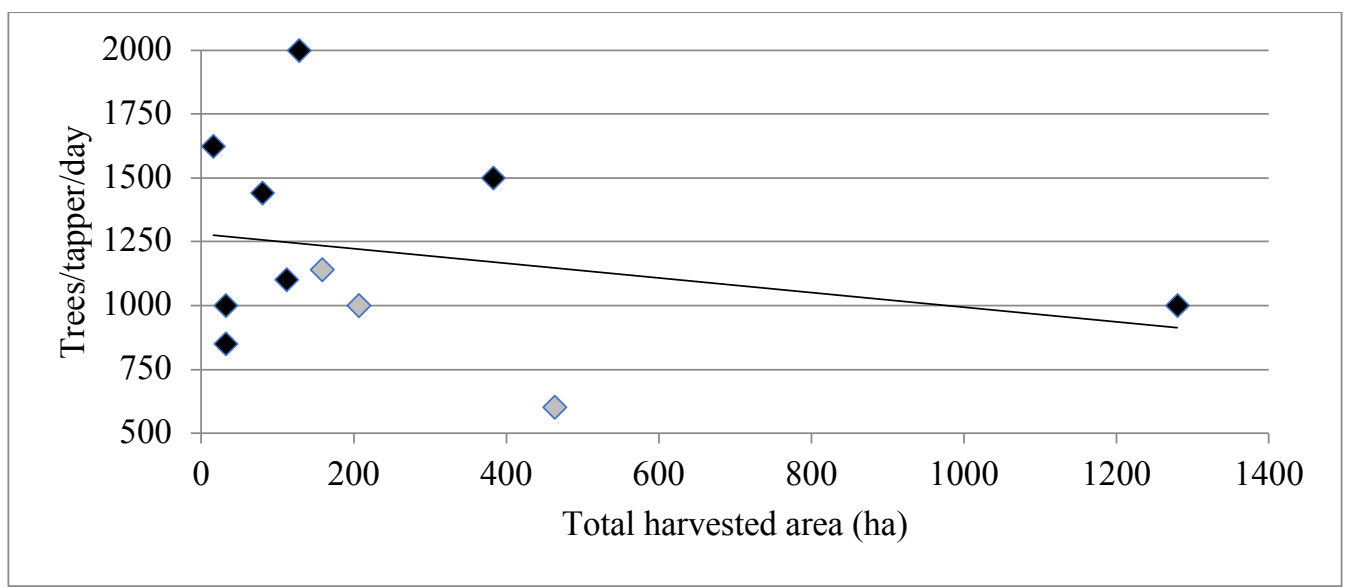

Figure 5. Tapping task as a function of the total harvested rubber area

Grey diamonds represent for enterprises and black diamonds family business farms

The number of tappers was considered related to the number of supervisors. A supervisor could be a chief of squad, an assistant chief of squad, a manager or an assistant manager, depending on the organization of the plantation. When the size of the plantation increased, the level of supervision tended to be reduced, ranging from 1:2 (one supervisor for two tappers) to 1:6 for small size structures and up to 1:35. Below 40 ha, supervision was tight and decreased in intensity with an increase in the amount of productive rubber. This trend also needs to be confirmed on a bigger sample of farms. 


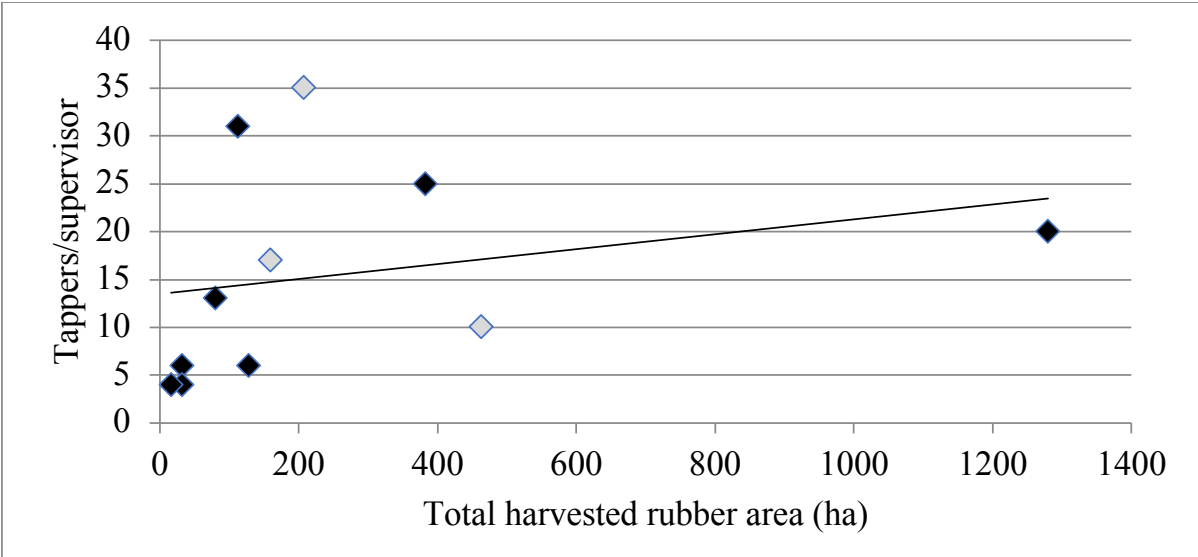

Figure 6. Level of supervision of tappers according to the total harvested rubber area Grey diamonds represent enterprises and black diamonds family business farms

The size of the tapping task (number of tapped trees per tapper per day) was independent of the level of supervision (Figure 7). Further investigation of the effect of supervision on tapping would need to take the actual number of tapping days, the quality of tapping and the level of production into account.

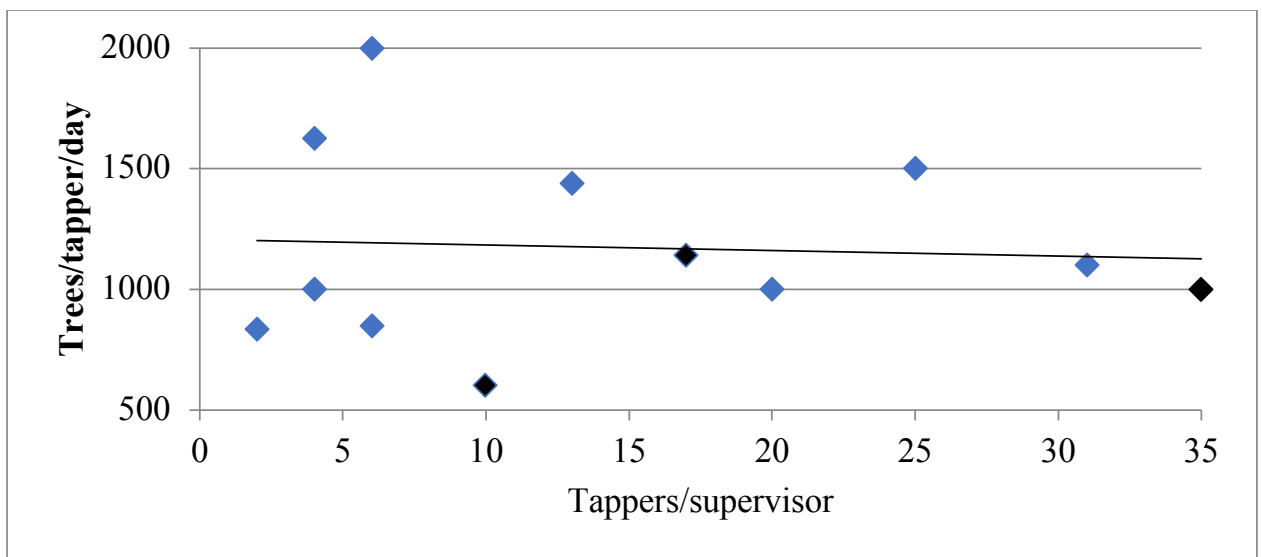

Figure 7. Tapping task according to the level of supervision

Grey diamonds represent enterprises and black diamonds family business farms

\subsection{Rubber technical practices}

Due to the time constraints of the interviews and the fact that only one person per holding could be interviewed, complete data was not recorded for all enterprises and FBFs. Consequently, data collection was focused on mature plantations and in particular on weeding, fertilization and harvesting. Data were collected from 10 respondents (the other holdings had no mature rubber trees or had less than one year of harvesting at the time of the survey).

The cleaning of the plantation was usually done mechanically (using a weeding machine) with a variable frequency ( 1 to 5 weedings per year) depending on weed development. Only one holding did not weed the plantation at all. 
All the holdings applied fertilizer twice a year during the mature period. The use of chemical fertilizer was widespread but five holdings applied organic fertilizer, two of whom only used on this type of fertilizer, whereas the three others used organic fertilizer as a complement to chemicals. We were able to collect information on chemical fertilizer from four holdings (one enterprise and three FBFs) that enabled us to calculate the supply of each of the nutrients, N-P-K (Table 5).

Table 5. Doses of nitrogen $(\mathrm{N})$, phosphorus $(\mathrm{P})$ and potassium $(\mathrm{K}), \mathrm{kg} / \mathrm{ha} / \mathrm{year}$, used during the mature period of the plantations compared with RAOT recommendations and use by smallholders

\begin{tabular}{lccccc}
\hline & RAOT & C3 & FBF6 & FBF8 & FBF10 \\
\hline $\mathrm{N}$ & 150 & 152 & 100 & 83 & 75 \\
\hline $\mathrm{P}$ & 25 & 76 & 33 & 33 & 21 \\
\hline $\mathrm{K}$ & 90 & 190 & 83 & 83 & 21 \\
\hline
\end{tabular}

The enterprise farms followed RAOT recommendations for nitrogen $(\mathrm{N})$ but used far more phosphorous $(\mathrm{P})$ and potassium $(\mathrm{K})$ fertilizers than recommended (respectively, 3 and 2 times more). We are unable to make further comments here without information on the quality of the soil in the plantations. All FBFs were below RAOT recommendations for $\mathrm{N}$. Two holdings followed RAOT for $\mathrm{K}$ (the two others being below). And all FBFs were close to RAOT recommendations for $\mathrm{P}$. The quantities of $\mathrm{N}$ and $\mathrm{K}$ were highly variable, but rather uniform for $\mathrm{P}$. The basic recommendation came from RAOT but each holding used its own human resources or experience (mainly acquired in the South of Thailand) to adapt to the actual soil situation with or without soil analyses. Some may have used specialized staff to provide guidance to plantation manager; in the case of enterprises, these were permanent staff, not attached to a single plantation.

The age of the trees at opening was very variable; it ranged between 5.5 up to 12-13 years old depending on the growing conditions. More than half of the holdings ( 6 out of 10 ) used the $S / 32 d 3$ tapping system (i.e. the length of the cut was a third of the rubber tree circumference and the tapping frequency was two days of tapping followed by one day of rest) while three used $\mathrm{S} / 3 \mathrm{~d} 2$ (tap one day and stop one day) and one $\mathrm{S} / 42 \mathrm{~d} 3$ (a quarter of the rubber tree circumference, tap two days followed by one day of rest). It is interesting to note that none of these large holdings used low intensity tapping frequency compensated by the use of stimulation. Only one holding used stimulation, but its use was not related to the reduction of tapping frequency but to the desire to maintain the level of income for the tappers.

\section{Discussion}

\subsection{Limited land concentration dynamics towards entrepreneurial agriculture}

This study showed that the recent development of large plantations in the rubber sector remained limited in Thailand. This result is consistent with the minor role of these forms of production in Thai rubber sector: with an average area around 63 ha, they represented only $3.5 \%$ of total holdings (RRIT, 2013 cited by Somboonsuke and Wittayaprasat, 2013). 
In addition, this (limited) dynamics of expansion of large rubber plantations involved mainly family business farms (together with family farms who also largely contributed to the recent expansion of rubber plantations, Chambon et al., 2016). This change in the agrarian structure in the Thai new rubber producing areas differs from what has been observed in neighboring countries (Laos, Cambodia, Myanmar); indeed, these countries experienced a recent resurgence of large rubber plantations within a structure that can be defined as enterprise agriculture and with much bigger landholdings than in Thailand: the medium size of rubber concessions in other countries (Laos, Cambodia) was 8,000 ha (Byerlee, 2014) whereas in Thailand, the maximum is less than 1,500 ha. Byerlee (2014) identified three main factors explaining the "rebirth of plantations on the frontier": the increase in commodity price, access to cheap land notably through concession and weak state institutions. In Thailand, high rubber price was not systematically mentioned by the respondents as a driver, but it certainly encouraged the establishment of large plantations. The comparatively low price of land in the new rubber producing areas compared with other regions, particularly in the historical rubber producing areas (Chambon et al., 2016) facilitated access to land for the investors with available capital. However, unlike its neighbors, Thailand did not adopt any policy to attract transnational investors: direct foreign investment in the agricultural sector was limited compared to other sectors and focused on the food processing sector (FAO, 2012). And policy is a key factor in explaining the distribution of agrarian structure in cash crop sectors (Bissonnette and De Koninck, 2017). As a result, the development of large plantations relied on domestic investment. So in a way, also history repeated itself in Thailand. But the history differed from what was observed elsewhere (Byerlee, 2014).

In Thailand, the development of large rubber plantations through land purchase avoided the problems connected with land grabbing (Kenney Lazar, 2012; Global Witness, 2013). However, this contributed to the land concentration process observed in Thailand (Podhisita, 2017), and probably resulted in increasing the polarization of the countryside with capitalist farmers (family business farms and enterprises) on the one hand and landless laborers (or very smallholders) on the other (Bernstein, 2002) which happened in Thailand (Podhisita, 2017) and has already been observed in the rubber sector in Southern Thailand (Kongmanee, 2015). But so far, in the Thai rubber sector, most capitalist farmers remain family agriculture. The policy favoring family agriculture that has long been implemented by Thailand should continue to protect small and medium landholders from land grabbers. Land concentration is probably not to be encouraged as long as there are still some farmers interested in continuing to farm. Measures should be taken to allow small farmers to maintain their activities on their own land i.e. by ensuring that their farming activities can provide the households with sufficient income and good living conditions to prevent them leaving the farming sector.

\subsection{A unique contractual arrangement for tapping and same labor issues for all types of holdings}

In quite a counter intuitive way, the mobilization of labor in large family business and enterprise farms follows the widespread pattern of labor contracts in family farms that hire labor under share-tapping contracts for latex harvesting. This is almost the only type of labor contract on family farms and has persisted since the introduction of rubber 
in Thailand (Kongmanee, 2015). Hired laborers paid with wages for latex harvesting account for a very limited share and appears to be a complement or to be used in a limited number of cases. Thus it is the main form of labor contract for hired tappers in most rubber producing countries (Chouhan and Bhowmik, 2017). The profound reasons for this specificity of the Thai rubber sector probably have their origin in the history of the development of the sector.

Regarding access to labor, all the large scale holdings faced the same difficulties: finding and keeping skilled tappers that is getting even more difficult with low rubber prices. In some places, they had to recruit foreign tappers due to labor shortages (job opportunities in other sectors attract labor away from the rubber sector). In the sample, two holdings (one enterprise and one FBF) mentioned they had stopped tapping part of their plantation because they lacked skilled tappers.

Finally, the issues regarding labor mobilization in large landholdings were similar to those faced by the average family business farms: availability and stability of the commitments by share-tappers on the one hand and the quality of labor and quality control on the other (Kongmanee, 2015; Russo et al., 2017). The large farms addressed these issues in a slightly different way; their labor organization exhibits several levels of management between top management and share-tappers. These layers obviously do not exist in average family business farms that use only one or two share-tappers because of the scales of the plantations.

Because the rubber sector requires rather high quantities of skilled labor, public policies should ensure the availability of the labor to work in the rubber plantation and their skill. This implies improving labor productivity in rubber plantations to enable workers increasing their income, to make latex harvesting a more attractive activity. In addition, tappers require more training to make sure that all the tappers have the minimum knowledge and skill needed to harvest the latex.

\subsection{Similar technical and organizational trends and the same problems facing all types of holdings}

The technical and organizational models used by the large holdings (enterprise and family business farms) were rather homogeneous and presented several similarities with smaller holdings. Although holdings cultivating cash crops at large scale are often specialized in one commodity, pluriactivity, which has long been acknowledged to be the norm in family agriculture (Alobo-Loison, 2015; Losch et al., 2012) was very common in this study.

As analyzed, the patterns of technical practices used in large family business and enterprises farms show similarities with the current technical practices used by the average family or small family business farms. Fertilization based on official recommendations and adapted to local conditions did not differ much from the practices observed in the Northeastern rubber smallholdings (Chambon et al., 2017). Variable ages for opening the trees and starting latex harvesting, practices for cleaning the plantation, be it manual or through herbicides, as well as latex harvesting, are not more standardized than would be expected on such large farms. The most surprising was the latex harvesting practices. While large holdings usually try to maximize the productivity of the factors involved in production, our survey showed that the enterprises and large family business farms used high intensity tapping systems that are less labor productive 
than the low intensity tapping systems (Sainoi et al., 2017). Some large holdings used the same wrong practices usually found in the smallholdings: use of ethylene stimulation with no accompanying change in harvesting practices to increase production, whereas stimulation should be used to compensate for the reduction of tapping frequency.

This clearly underlines an urgent need for the government to improve the transfer of knowledge to all the producers especially concerning the management of the mature period of the plantations. Identifying and implementing innovative methods for the adoption of the good agricultural practices should be a priority for policy makers.

\subsection{Some limits of the study}

Even if the findings of this study are not challenged, certain limitations should be noted. First, the sample was very small, which may limit the scope of the results. However, this should to be put into perspective given the limited number of large landholdings, plus our sample does seem to cover the possible diversity. Second, it was only possible to interview one person per holding. This means we only obtained a partial view of the farm, even if the interviewee was a knowledgeable person able to have a broad overview of the investment in rubber and its management. Since in many cases, it was not possible to meet the top management, the interviewee was not always aware of or able to communicate the motivations of the owners. And it was sometimes difficult to address economic and particularly financial issues, given the reluctance of the interviewee to discuss these aspects in detail. However, this work produced original data documenting some forms of production that have rarely been studied before. Finally, the organization of the field work and the available resources did not permit us to deepen the approach to communities to address the relations between family farmers and these large farms that concentrate lands. This would be an interesting topic for future research even if the present study showed that in the end, the expansion of large holdings was limited in both the number and the size of the holding. Locally, this development could affect family farms.

\section{Conclusion}

This study of recent changes in the Thai rubber sector focusing on the expansion of large-scale rubber plantations showed that another model (persistence of the family farms over the enterprises) than the one observed in many other countries (from enterprises to family farms followed by recent resurgence of enterprises farms) exists. It also differs in that Thailand has not being a target for foreign large-scale acquisition and investment. Therefore, this study supports Bissonnette and De Koninck (2017, 934) claim that "the argument which states that it is only a question of time before smallholders give way to large plantations throughout Southeast Asia is supported by neither historical nor contemporary trajectories of the smallholding sector". On top of that, one of the findings questions the development of large-scale holdings based on salaried labor, i.e. the adoption of pattern of labor organization found in family farms by enterprises when one could have expected a more standard wage contract. This specificity is certainly linked to the nature and the specific conditions of the labor for latex harvesting (night work among others) that render the share contract attractive for both the owner and the tapper - whether the owner is a family or an enterprise. This 
picture corresponds to recent contributions based on other data sets. The future of rubber development probably depends on the family business farms, a form of production that is tending to expand in Thailand (Podhisita, 2017). Because of the socio-economic changes (such as labor constraints, higher levels of education in rural areas, increasing interest in non-agricultural activity sectors), this form of production will certainly become more and more important for agriculture in developing countries. Government policies need to take these changes into consideration. Family business farms are a heterogeneous category of farms. Governance varies markedly across family structures. Exploring this category of holdings into more detail would provide insights into the transformation of the agrarian structure that would be useful for policy makers. Analyzing the other stakeholders concerned by land polarization (those who sold their land holdings), the drivers and the consequences of their decision, would complete the understanding of the recent agrarian change. In Thailand, the interest would be to follow-up the transformations of family business farms while in the neighboring countries one of the issues would be to study the organization and the viability of largescale enterprise farms.

\section{References}

Alobo Loison, S. 2015. Rural livelihood diversification in Sub-Saharan Africa: A literature review. Journal of Development Studies, 51(9): 1125-1138, DOI: 10.1080/00220388.2015.1046445

Bauer, P. T., 1948. The rubber industry. A study in competition and monopoly. The London School of Economics and Political Science. Longmans, Green and Co, London, New York, Toronto.

Bélières, J. F., Bonnal, P., Bosc, P. M., Losch, B., Marzin, J., and Sourisseau, J. M. 2015. Family farming around the world. Definition, contributions and public policies. Collection A savoir $\mathrm{n}^{\circ} 28$. AFD, CIRAD, Paris, http://www.afd.fr/webdav/site/afd/shared/PUBLICATIONS/RECHERCHE/Scientif iques/A-savoir/28-VA-A-Savoir.pdf

Bernstein, H. 2002. Land reform: taking a long(er) view. Journal of Agrarian Change, 2(4): 433-463, DOI: 10.1111/1471-0366.00042

Bissonnette, J.F. and R. De Koninck. 2017. The return of the plantation? Historical and contemporary trends in the relation between plantations and smallholdings in Southeast Asia. The Journal of peasant Studies, 44(4):918-938, DOI: 10.1080/03066150.2017.1311867

Borras, S.M. and J.C. Franco. 2012. Global Land Grabbing and Trajectories of Agrarian Change: A Preliminary Analysis. Journal of Agrarian Change, 12(1):34-59, DOI:10.1111/j.1471-0366.2011.00339.x

Byerlee, D. 2014. The fall and rise again of plantations in Tropical Asia: history repeated? Land, 3:574-597, DOI:10.3390/land3030574

Chambon, B., F. Ruf, C. Kongmanee, S. Angthong. 2016. Can the cocoa cycle model explain the continuous growth of the rubber (Hevea brasiliensis) sector for more than a century in Thailand? Journal of Rural Studies, 44: 187-197, DOI: 10.1016/j.jrurstud.2016.02.003 
Chambon, B., X.L. Dao, U. Tongkaemkaew, F. Gay. 2017. What determine smallholders' fertilization practices during the mature period of rubber plantations in Thailand? Experimental Agriculture: 1-18, DOI: 10.1017/S0014479717000400

Chouhan, P. and I. Bhowmik. 2017. Labour market conditions of natural rubber plantations in Tripura: an inquiry. Social Change and Development, vol. XIV:55-69

FAO. 2007. A system of integrated agricultural censuses and surveys, volume 1 World Programme for the Census of Agriculture 2010, statistical development series, 11 FAO, Rome

FAO. 2012. Trends and impacts of foreign investment in developing country agriculture. Evidence from case studies. FAO, Rome

Fox, J. and J.C. Castella. 2013. Expansion of rubber (Hevea brasiliensis) in Mainland Southeast Asia: what are the prospects for smallholders? The Journal of Peasant Studies, 40(1):155-170, DOI: 10.1080/03066150.2012.750605

Global Witness. 2013. Rubber barons. How Vietnamese companies and international financers are driving land grabbing crisis in Cambodia and Laos. Global witness limited, London

Hayami, Y. 2002. Family farms and plantations in tropical development. Asian Development Review, 19(2):67-89

Kenney-Lazar, M. 2012. Plantation rubber, land grabbing and social property transformation in southern Laos. The Journal of Peasant Studies, 39(3-4):10171037, DOI: 10.1080/03066150.2012.674942

Kongmanee, C. 2015. Path dependence of agrarian change: an institutional economic analysis of the rubber economy in Southern Thailand. Unpublished doctoral dissertation, Montpellier SupAgro, France.

Larsson, T. 2007. Intertextual relations: the geopolitics of land rights in Thailand. Political Geography, 26:775-803, DOI: 10.1016/j.polgeo.2007.05.003

Losch, B., S. Fréguin-Gresh, E.T. White. 2012. Structural Transformation and Rural Change Revisited: Challenges for Late Developing Countries in a Globalizing World. World Bank, Washington DC

Petric, B. 2011. The land rush. Transnational strategies for land grabing. Transcontinentales [online] 10/11. Online since 21 December 2011

Podhisita, C. 2017. Household Dynamics, the Capitalist Economy, and Agricultural Change in Rural Thailand. Southeast Asian Studies, 6(2):247-273, DOI: 10.20495/seas.6.2_247

Russo, M, Bouquet E. and Chambon B. 2017. Sharing more than rubber: the economic and social lives of share-tapping contracts in Southern Thailand. 11èmes Journées de recherché en Sciences Sociales (SFER), 14-15 December 2017 Lyon

Sakarindr, P. 1979. An econometric study of Thai rubber industry and the world rubber market. Retrospective Theses and Dissertations. 6620.

Sainoi, T., S. Sdoodee, R. Lacote, E. Gohet. 2017. Low frequency tapping systems applied to young-tapped trees of Hevea brasiliensis (Willd. ex A. Juss.) Müll. Arg. in Southern Thailand. Agriculture and Natural Resources, 51(4): 268-272, DOI: 10.1016/j.anres.2017.03.001 
Somboonsuke, B., and P. Wettayaprasit. 2013. Agricultural system of natural Para Rubber smallholding sector in Thailand: system, technology, organization, economy, and policy implication. Hat Yai: Department of Agricultural Development, Prince of Songkla University.

Stifel, L.D. 1973. The growth of the rubber economy of Southern Thailand. Journal of Southeast Asian Studies, 4(1) :107-132 , DOI : 10.1017/S0022463400016441 